\title{
THE END OF THE WEST?
}




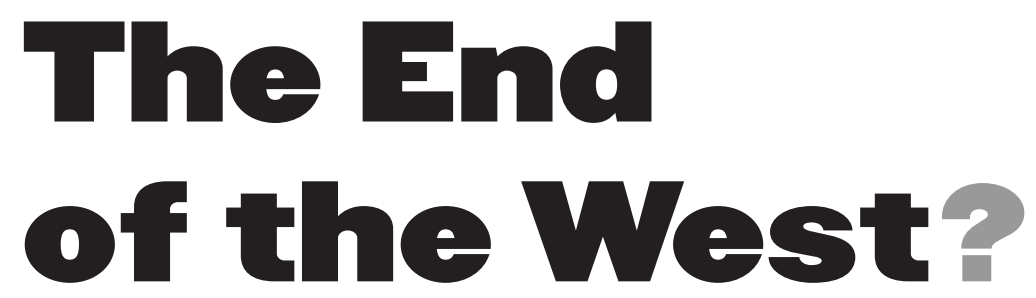

Crisis and Change

in the Atlantic Order

EDITED BY

Jeffrey Anderson

G. John Ikenberry

Thomas Risse

Cornell University Press

Ithaca and London 


\section{Copyright () 2008 by Cornell University}

All rights reserved. Except for brief quotations in a review, this book, or parts thereof, must not be reproduced in any form without permission in writing from the publisher. For information, address Cornell University Press, Sage House, 512 East State Street, Ithaca, New York 14850.

First published 2008 by Cornell University Press

First printing, Cornell Paperbacks, 2008

Printed in the United States of America

\section{Library of Congress Cataloging-in-Publication Data}

The End of the West? : crisis and change in the Atlantic order / edited by Jeffrey Anderson, G. John Ikenberry, Thomas Risse.

$$
\text { p. } \mathrm{cm} \text {. }
$$

Includes bibliographical references and index.

ISBN 978-0-8014-4639-9 (cloth : alk. paper) — ISBN 9780-8014-7400-2 (pbk. : alk. paper)

1. Europe-Foreign relations-United States. 2. United States-Foreign relations-Europe. I. Anderson, Jeffrey J. II. Ikenberry, G. John. III. Risse, Thomas. IV. Title.

D2025.5.U64E53 2008

$327.4073-\mathrm{dc} 22$

2007039504

Cornell University Press strives to use environmentally responsible suppliers and materials to the fullest extent possible in the publishing of its books. Such materials include vegetable-based, low-VOC inks and acid-free papers that are recycled, totally chlorine-free, or partly composed of nonwood fibers. For further information, visit our website at www.cornellpress.cornell.edu. 